\title{
Analysis of Effects of Economic Growth, Human Development Index, Population, Unemployment and Investment on Poverty Levels in the North Sumatra Province
}

\author{
Marisa Br Sinuraya ${ }^{1}$, Raina Linda Sari², Irsad Lubis ${ }^{3}$ \\ ${ }^{1}$ Master of Economics Students, Faculty of Economics and Business, Universitas Sumatera Utara, Indonesia \\ ${ }^{2,3}$ Lecturer of Master Economics, Faculty of Economics and Business, Universitas Sumatera Utara, Indonesia
}

\begin{abstract}
The research aims to examine and analyze effects of economic growth, human development index (HDI), population, unemployment, and investment on poverty levels in the North Sumatra Province. The research uses quantitative data type, while the data source is obtained from secondary data in the quarterly form of 2010-2019. The data are analyzed with the model of Autoregressive Distributed Lag (ARDL) analysis. The results of ARDL analysis of economic growth variables and HDI have negative and significant effects on poverty levels in the short term and long term. Unemployment variable has a significant positive effect on poverty levels in the short term however insignificant in the long term and investment variable has an insignificant positive effect on the poverty level in the short and long term.
\end{abstract}

Keywords: Economic Growth, HDI, Population, Unemployment, Investment, Poverty

\section{INTRODUCTION}

Development is a process of change leading patterns of a society that allows the realization of a better and more and achieve the goal that embodies the people of Indonesia that is fair, competitive, advanced and prosperous. One of Indonesia's development goals add to the performance of the economy in order to generate jobs and organize your life deserves to be the welfare of the people. Development should be implemented if a country wants to improve the welfare of society as well as improve the standard of living, one of the efforts to reduce the level of poverty. Poverty is one of the diseases of the serious economic, so it must be resolved or at least reduced (Kurniawan, 2011).

In 2015 the Millennium Development Goals (MDG's) are replaced by the Sustainable Development Goals (SDGs). The SDGs are the sustainable development goals published 21 October 2015 as the ambition of the joint development up to 2030, which has 17 development goals berkelanjutanya it without poverty, without hunger, the life of a healthy and prosperous, quality education, gender equality, clean water, decent work and economic growth, clean energy and affordable, innovation and infrastructure, reduced inequalities, industry, consumption and production who is responsible, marine ecosystem, the ecosystem of the mainland, the climate change mitigation, peace justice and institutional tough, a partnership to reach the goal.

The issue of poverty is also mentioned in the 1945 constitution Article 31 Paragraph 1 where "the poor and the orphans maintained by the state”. In this case it means effort in the reduction of poverty in Indonesia is one of the purposes 
Marisa Br Sinuraya et.al. Analysis of effects of economic growth, human development index, population, unemployment and investment on poverty levels in the north sumatra province.

of planning development and economic growth.

In a society that is fair, competitive, advanced and prosperous government's various policies to one of them tackling poverty. Quote Ernanda And Gaol in (2017) which states the existence of the program and activities to the alleviation of poverty by the government, among others: (1) the Family Hope Program (PHK), which help for the Very Poor Households (RTSM) in the form of social protection by providing cash assistance non-cash, (2) Program Rastra Rice Prosperous namely assistance in the form of rice for poor families, and (3) Program of the Joint Business Group (Kube) is a group established to do business in improving well-being through Programs of Social Welfare. The government always reflect how the way in tackling poverty from year to year, but the poverty in Indonesia is not also significant, although the numbers in CPM poverty reduction, but qualitatively not show the impact of changes in real but there where poverty is getting worse every year.
According to Word Bank (2004), the causes of poverty, namely because of the lack of income and assets (lack of income and assets) to meet basic needs such as food, clothing, housing and the level of health and education acceptable (acceptable). Poverty is also associated with the limitations of the field work that are categorized as poor (the poor) do not have a job (unemployed), and so also on the level of education and health in general not adequate. In this regard, various policies have been conducted and are being conducted in a thorough and integrated by the Government for poverty alleviation. Poverty is one of the centers of attention in any country. Some other factors that lead to poverty, namely the level of investment is still below the standard, high unemployment and slow economic growth. Gap between the rich and the poor people in Indonesia has widened due to the high disparity between regions due to the uneven distribution of income which becomes the root of the problem of poverty.

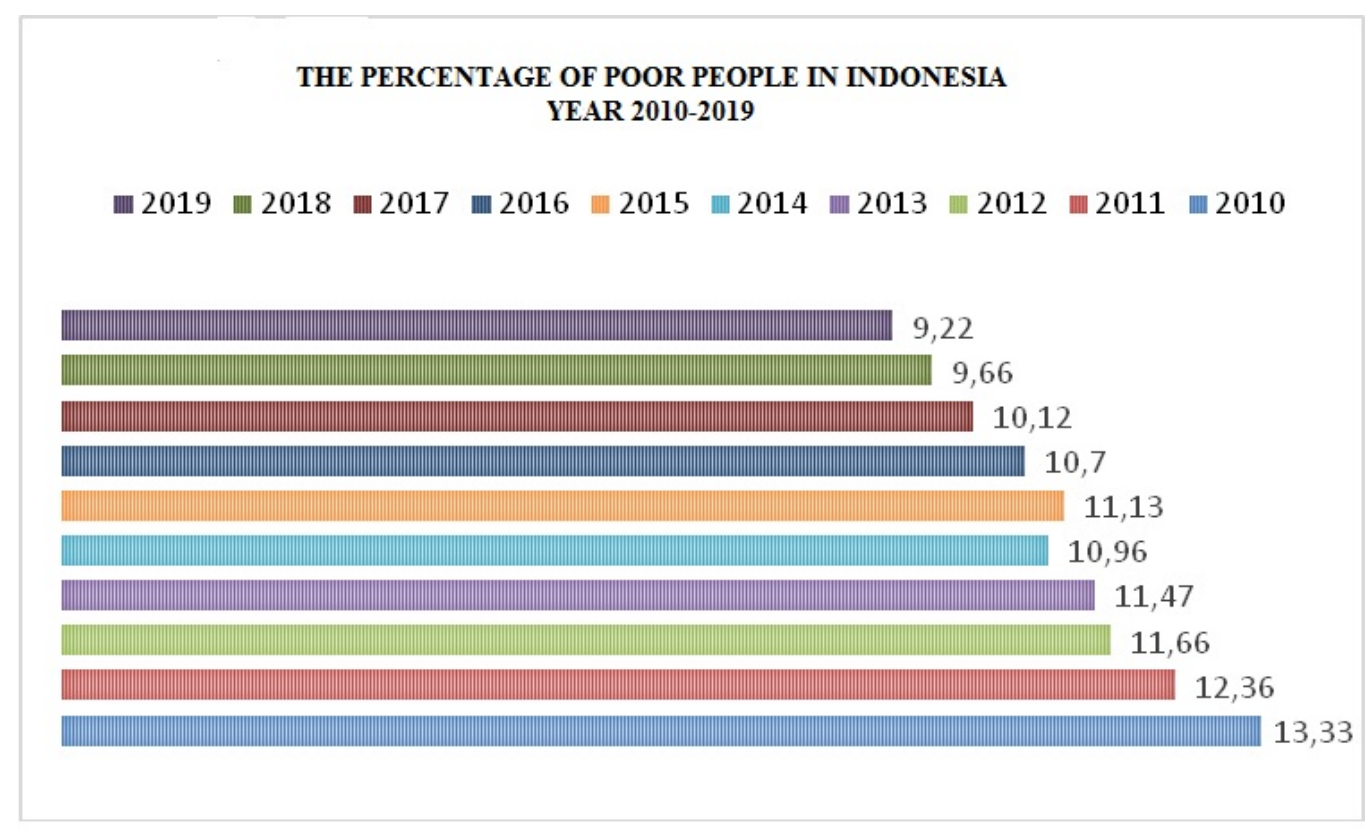

Source: Central Bureau Of Statistics

Figure 1 Percentage Of Poor People In Indonesia 2014-2019

The level of poverty in Indonesia in the period of 2010 until 2014 experience decreased by of 13.13, 12,36, 11,66, 11,47,
10,96 percent and then increased in 2015 amounted 11,13 percent, then decreased in 2016 amounted to 10.7 percent, and 
Marisa $\mathrm{Br}$ Sinuraya et.al. Analysis of effects of economic growth, human development index, population, unemployment and investment on poverty levels in the north sumatra province.

increased in the year 2017sebesar 10,12 percent and decreased in the year 2018 to 2019 by 9,66, 9.22 percent. The seriousness of the Government of Indonesia to reduce the level of poverty can be seen from (RPJMN) tahun 2015-2019, with the purpose of lowering the level of poverty in Indonesia to be 6-8 per cent at the end of 2019. From the Central bureau of Statistics in 2019 showed that the level of poverty in Indonesia by 9.22 percent. Although the percentage of poor population in 2019 was in the single digits i.e. 9.22 percent but still needs to be evaluated because the number of poor people is still great and still have not reached the target. Papua is a Province with the highest poverty rates 26,55 percent and Jakarta with the lowest poverty rate 3.42 percent. This means that the policy implemented by the government in an effort to decrease the level of poverty has not been effective and equitable. The province of North Sumatra is one example that still face the problem of poverty in Indonesia.

Based on data from BPS in 2019, the poverty rate in North Sumatra Province was ranked 18th out of 34 Provinces in Indonesia in 2019 with the percentage of the population of 8,83 percent.
Table 1 the Level of poverty In All Provinces In Indonesia 2019

\begin{tabular}{|l|l|l|}
\hline No. & Province & Poverty Level \\
\hline 1 & Papua & 26,55 \\
\hline 2 & Papua Barat & 21,51 \\
\hline 3 & Nusa Tenggara Timur & 20,62 \\
\hline 4 & Maluku & 17,65 \\
\hline 5 & Gorontalo & 15,31 \\
\hline 6 & Aceh & 15,01 \\
\hline 7 & Banten & 14,91 \\
\hline 8 & Nusa Tenggara Barat & 13,88 \\
\hline 9 & Sumatera Selatan & 12,56 \\
\hline 10 & Lampung & 12,30 \\
\hline 11 & Sulawesi Tengah & 12,18 \\
\hline 12 & DI Yogyakarta & 11,44 \\
\hline 13 & Sulawesi Tenggara & 11,04 \\
\hline 14 & Sulawesi Barat & 10,95 \\
\hline 15 & Jawa Tengah & 10,58 \\
\hline 16 & Jawa Timur & 10,20 \\
\hline 17 & Indonesia & 9,22 \\
\hline 18 & Sumatera Utara & 8,83 \\
\hline 19 & Sulawesi Selatan & 8,56 \\
\hline 20 & Jambi & 7,51 \\
\hline 21 & Sulawesi Utara & 7,51 \\
\hline 22 & Kalimantan Barat & 7,28 \\
\hline 23 & Maluku Utara & 6,91 \\
\hline 24 & Riau & 6,90 \\
\hline 25 & Jawa Barat & 6,82 \\
\hline 26 & Kalimantan Utara & 6,49 \\
\hline 27 & Sumatera Barat & 6,29 \\
\hline 28 & Kalimantan Timur & 5,91 \\
\hline 29 & Banten & 4,94 \\
\hline 30 & Kalimantan Tengah & 4,81 \\
\hline 31 & Kep. Bangka Belitung & 4,50 \\
\hline 32 & Kalimantan Selatan & 4,47 \\
\hline 33 & Bali & 3,61 \\
\hline 34 & DKI Jakarta & 3,42 \\
\hline & \multicolumn{1}{|c|}{ Source: Central Bureau Of Statistics } \\
\hline & & \\
\hline & & \\
\hline & & \\
\hline & & \\
\hline
\end{tabular}

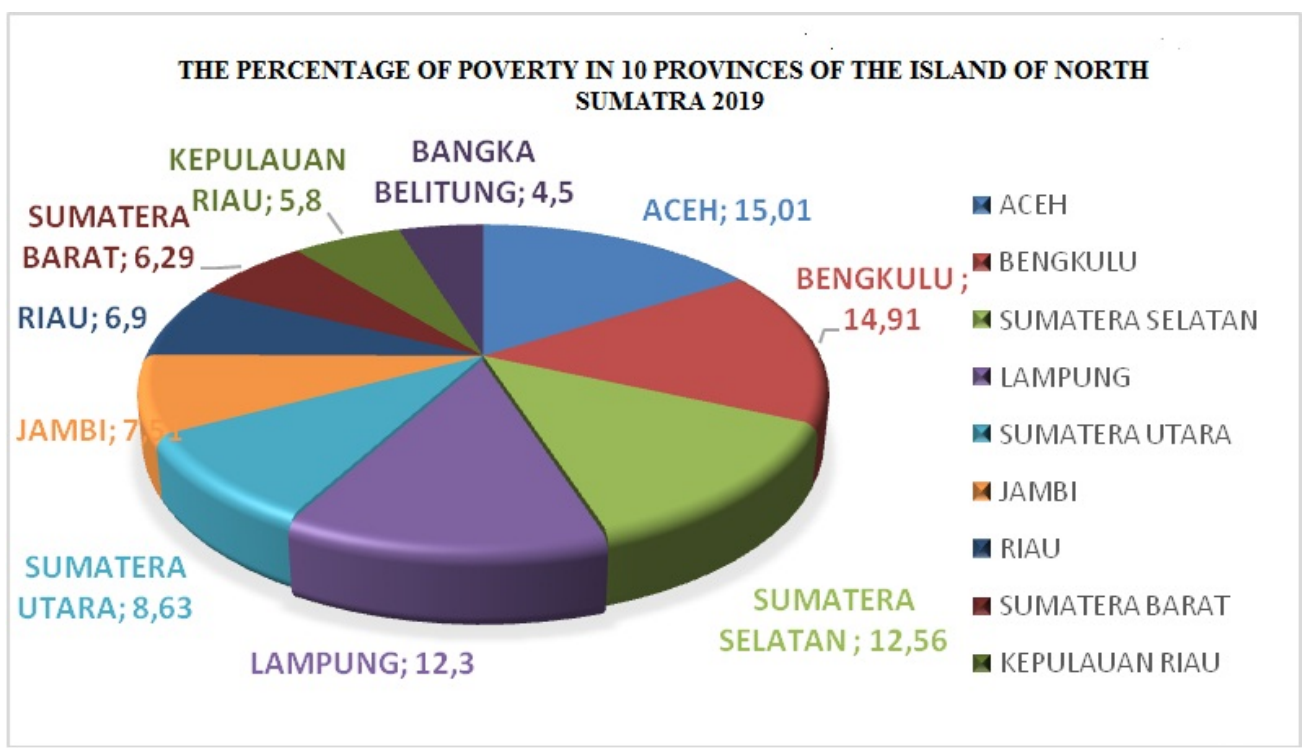

Source: Central Bureau Of Statistics

Figure 2 the Level of Poverty In 10 Provinces of the island of North Sumatra 2019

When compared with other according to the Regional Economic And Provinces on the Island of Sumatra, Financial Review (KEKR) the percentage of 
Marisa Br Sinuraya et.al. Analysis of effects of economic growth, human development index, population, unemployment and investment on poverty levels in the north sumatra province.

poverty level in North Sumatra is currently the fifth-highest and larger compared to Jambi by 7.51 percent, Riau 6.9 percent,
West Sumatra rate of 6.29 percent, Riau islands by 5.8 percent, Bangka Belitung amounted to 4.5 percent.

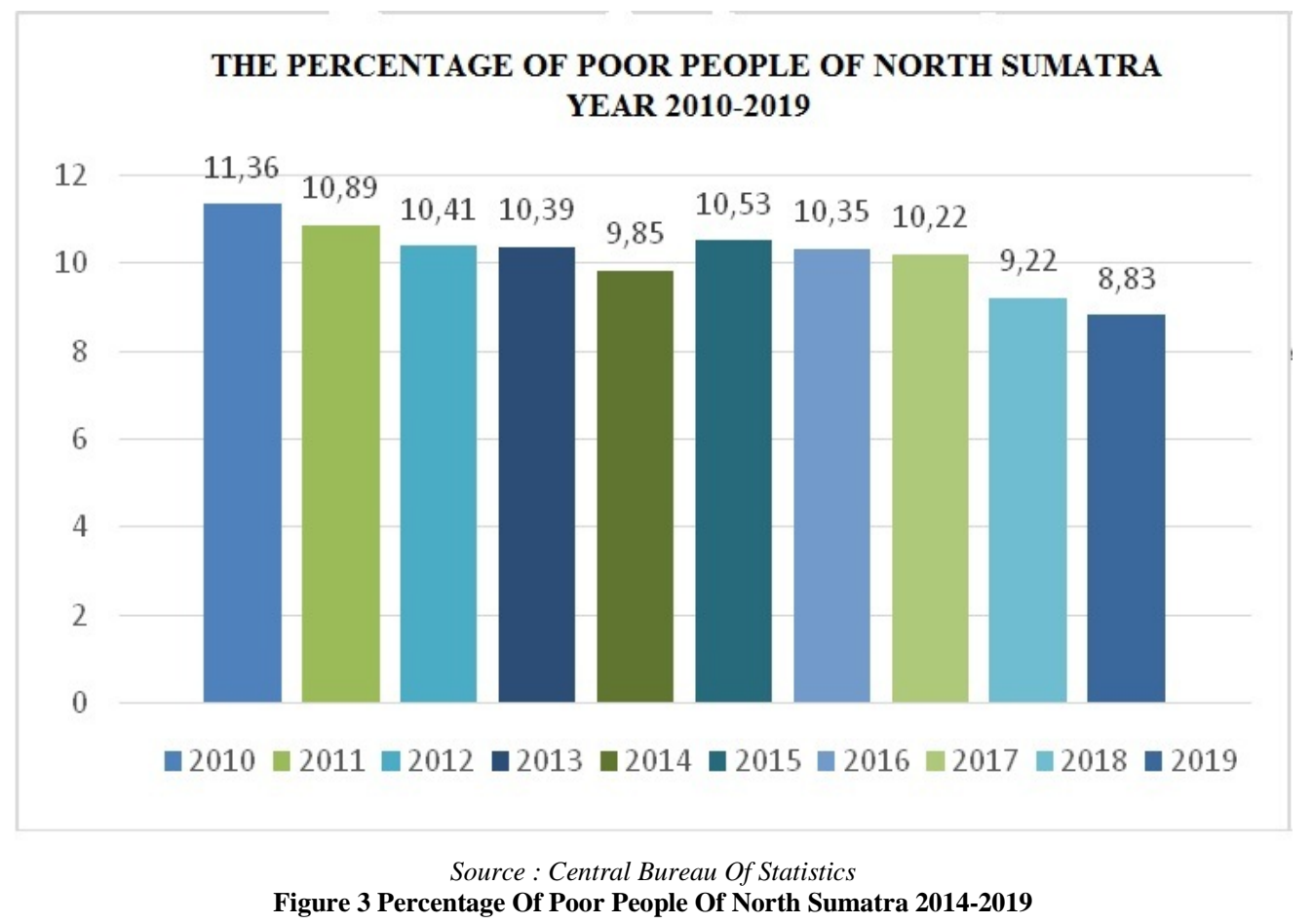

From the period of 2010 until 2019 of poor people experience a change. The percentage of poor people of North Sumatra 2010 to 2014 decreased by 11,36, 10,89, $10,41,10,39$ percent, then increased in 2015 amounted 11,13 percent, and in 2015 the highest percentage reached a 10.53 percent. One of the causes of the high percentage of the population is poor because of the low percentage of economic growth in the year 2015 approximately 5.1 percent. In 2016, the percentage of poor people decreased by $-0,18$ percent to 10.35 percent. In 2017 the percentage of poor people has decreased back to 10.22 percent. 2018 the poor population decreased by 9.22 percent and in 2019, a decline of $-0,39$ percent to 8,83 percent. It is still not good considering in 2019 the Government of North Sumatera Province targeting the level of poverty in the RPJMD Provinsi Sumatera Utara tahun 2018-2022, which is 6 percent. In fact, in 2019 alone poverty remains of 8,83 percent. This suggests that the target of the government in an effort to reduce the poverty rate in North Sumatra is still not fully succeed. That is, although the rate of poverty decline in North Sumatra since 2016, but the rate of decline is still far from the estimates or target reduction of poverty by the government of North Sumatra.

Poverty is one of the diseases in the economy. The problems of poverty are complex and multidimensional therefore, poverty alleviation efforts must be comprehensive, covering various aspects of the life of the community, and implemented in an integrated manner (Machmud, 2016). In theory the presence of an effort to reduce the poverty level of the community with quality economic growth. Quality economic growth can diwujudksan with the policy of expansion of the work opportunity and maximize the productive investment in various sectors of the economy (Jonaidi, 2012). Actual poverty reduction has been carried out since the last three decades, namely the provision of basic needs such as food, health services and education, the expansion of employment opportunities, the development of agriculture, the provision of revolving fund through the credit system, 
infrastructure development and so on. From a variety of ways and poverty reduction strategy, the everything-oriented material, so that continuing to rely on the availability of the budget and the government's commitment. Besides, absence of the order of a democratic government to make the low acceptability, and community initiatives to address poverty in their own way (Hureirah, 2005).

Todaro (2016) show braid poverty and underdevelopment with the kinds of aspects of economic and non-economic. The three components of the causes of the backwardness and poverty of the community, namely the low living standards, low self-esteem and freedom, the third aspect of this has a relationship of reciprocity. The low standard of living caused by low levels of income, to low income is caused by the high employment growth, high unemployment and low investment per capita. While Maipita (2013) said factors, namely the growth of the local economy and the global low level of education and mastery of technology low, natural resources are unlimited, high population growth and political stability, which is not conducive.

Based on the opinion delivered Maipita and Todaro that one of the causes of poverty is the growth of the local economy. If viewed from the economic growth of North Sumatra which is measured by economic growth based on constant prices of the year 2000 of the year 2014-2019, the increase is quite significant. Following the development of the pace of economic growth in North Sumatra period 2014-2019.

Following the development of the fast economic growth of North Sumatra timeline of the year 2014-2019 in fugure 4 .

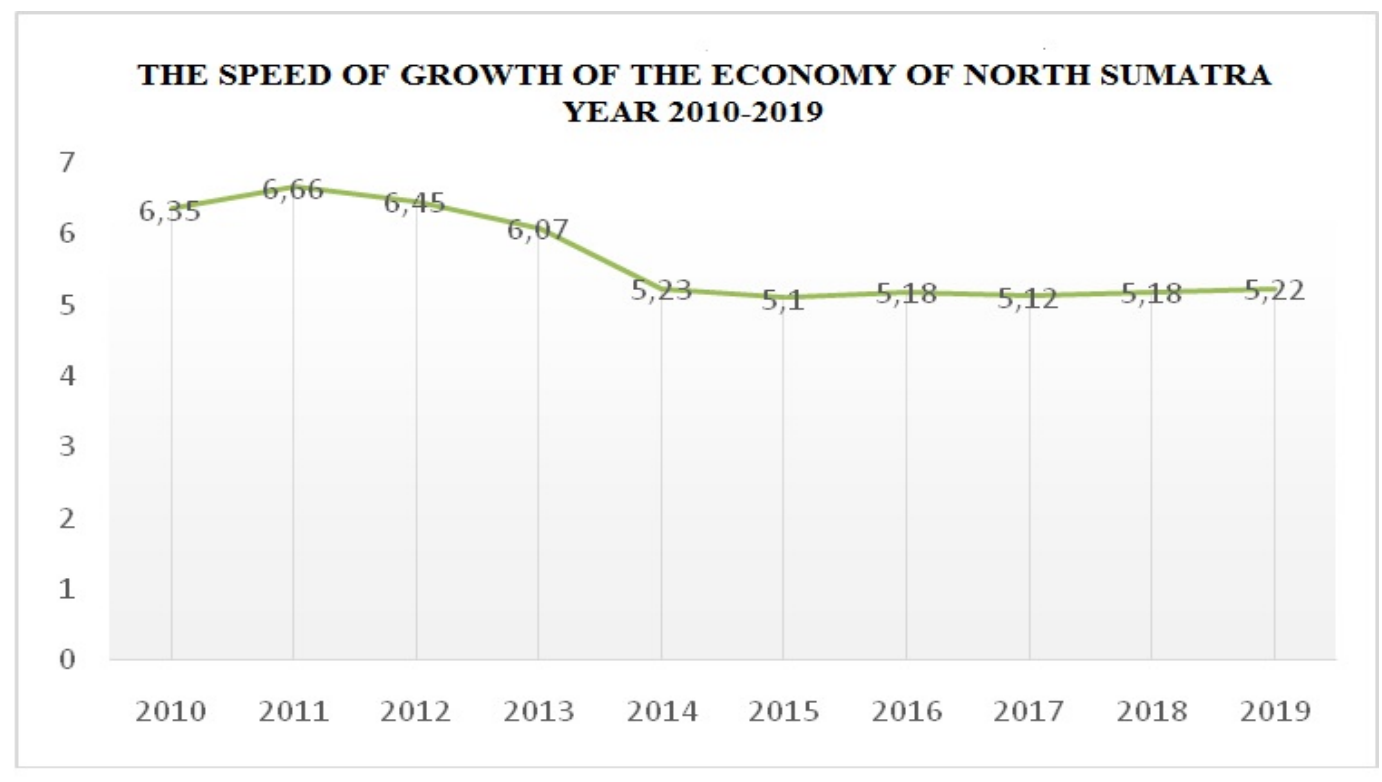

Source : BPS, North Sumatra

Figure 4 The Rate Of Development Of Economic Growth In North Sumatra 2014-2019

From figure 4 it can be seen that the economic growth in North Sumatra have fluctuated in the year 2010 of 6.35 and increased in 2011 by 6.66 percent in 2012 to 2014 decreased by the 6.45, 6,07, 5,23 percent. In 2015 economic growth decreased to 5.1 percent inversely proportional to the number percentage $d$ poverty on year increase of 0.73 percent, this is contrary to the research Marito Ritonga and Wulantika (2020) the results of his research stated economic growth negatively affect poverty in the Coal District, and in 2016 economic growth increased to 5,18 percent. In 2017 decreased by 0.6 percent to the 5.12 percent. In 2018 to 2019 economic growth increased by 5,18 and 5.22 percent. 
Marisa Br Sinuraya et.al. Analysis of effects of economic growth, human development index, population, unemployment and investment on poverty levels in the north sumatra province.

According to the views of The United Nations Development Programme (UNDP) to formulate IPM as one of the basic size in the determination of the goals and objectives of regional development can be used as a basis for determining the success of poverty reduction, namely education, health, and the parity of incomes. The low Human Development Index will result in low productivity of the population. Low productivity results in low revenue. This will have an impact on improving the welfare of society and the cause of the high number of poor people. The following data of Human Development Index in the Province of North Sumatra years 20142019.

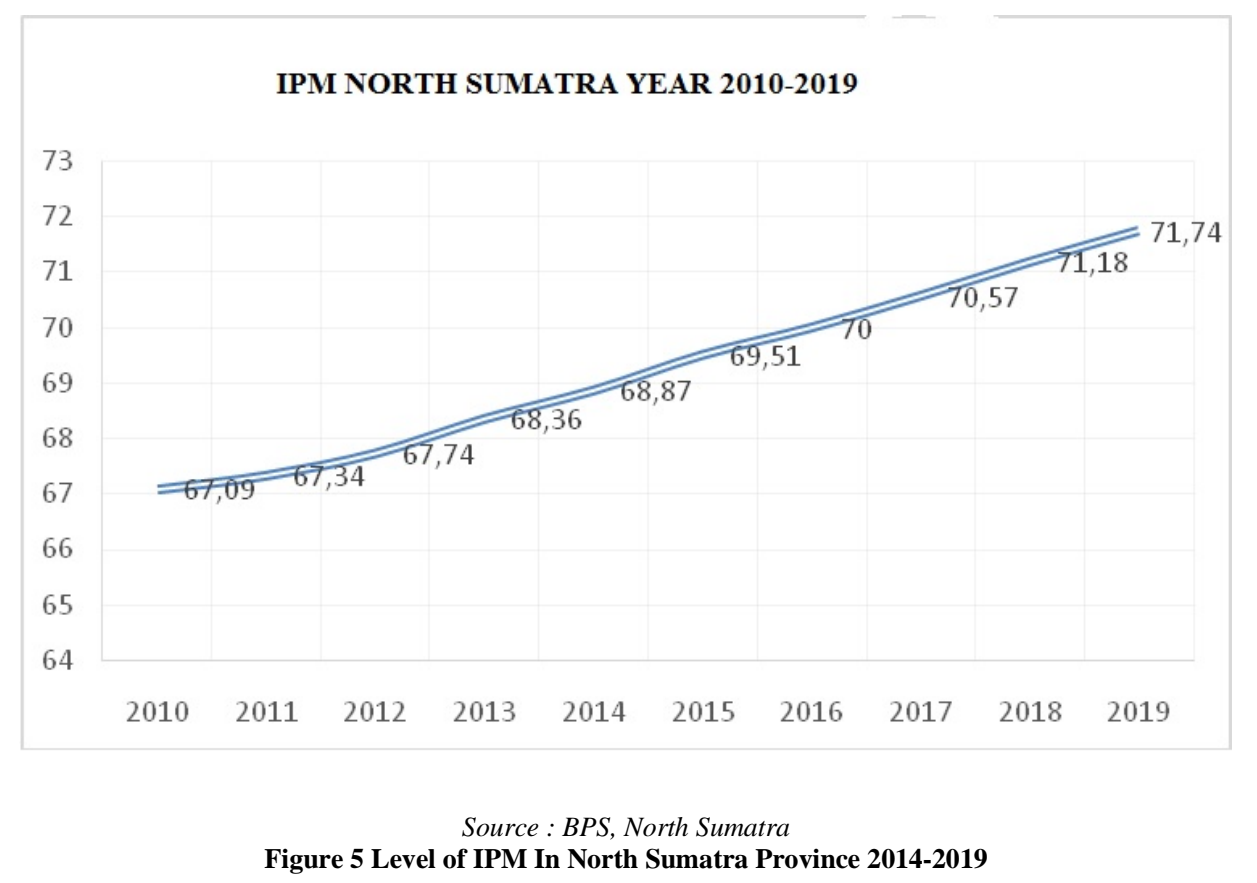

If seen the development level of IPM in North Sumatra in every year from 2010 to 2019 which slowly increased in line with the decrease in the number of poor people in period of the same year. This condition indicates that the level of IPM and the number of poor people has a relative strong relationships.

Other factors affecting poverty is the high population growth that has to do with the problems of poverty. Because of the number of uncontrolled population can result in not achieving the objectives of economic development, namely the welfare of the people and reduce poverty (Saputra,2011). High population growth that is not in balance with the improvement of the quality of the population as well as an increase in food resources will make poverty increased. With the increasing population can result in delays in the development of the economy. With the increasing population can result in delays in the development of the economy.

Other factors that also affect the level of poverty is unemployment. One determines the prosperity of society is the level of income. The income of the community reaches a maximum if the level of use of full employment can be realized. Unemployment will cause the effect of reducing the income of the community, and it will reduce the level of prosperity that has been achieved. The decline in the level of prosperity of the community will certainly increase the chances of trapped in poverty and will cause other problems that the political turmoil and social (Sukirno, 2010).

Efforts in reducing the level of poverty is important, this can be coupled with efforts to lower the unemployment rate. Efforts to lower the unemployment rate 
Marisa Br Sinuraya et.al. Analysis of effects of economic growth, human development index, population, unemployment and investment on poverty levels in the north sumatra province.

and lower level of poverty is equally important because if the community is not idle means having a job and income, then so is expected to meet the necessities of life. If the necessities of life can be met then there will be poor so it can be said with unemployment low, the poverty rate is also low.

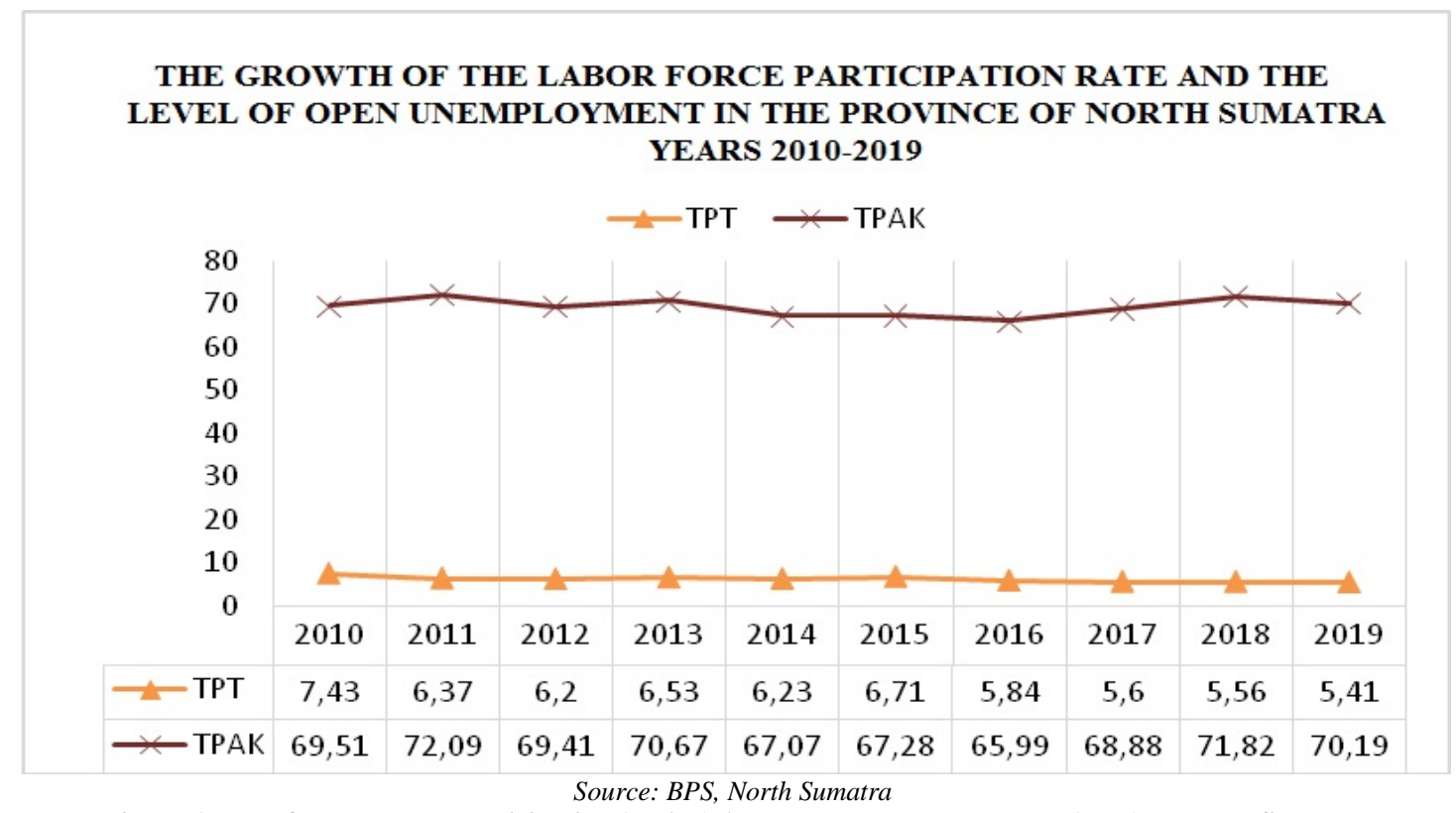

Figure 6 Rate of Labor Force Participation (TPAK) And the Unemployment Rate (TPT) In North Sumatra

In figure 7 can be seen from the years 2010 to 2019 as the unemployment rate or TPT slowly began to decline. Decrease in the number of unemployment was not showing the real economic progress in North Sumatra, given the Labor Force Participation Rate (TPAK) is increasing and is higher than the reduction of the Unemployment Rate (TPT). According To S. Mulyadi (2003), the trigger of the high labor force participation is increasing the population looking for work. It also means though the unemployment rate decreased, but the number of people who need work continues to grow. Decrease in the number of unemployment was not showing the real economic progress. Therefore, it should be immediately addressed by the government before growing serious and resulted in an increase in the amount of poverty.

Other factors that also affect the level of poverty is an investment. Investment is capital formation (capital) and the absorption of labor (labor). On the fact that investment is technology important in national income and economic growth (Adnan, 2010). Rapid economic growth is inseparable from the development of investment, namely the formation of capital. Capital formation is performed to enlarge the production capacity will increase national income or create more jobs. If the number of jobs is getting a lot will be followed with the large number of workers absorbed, then it will potentially reduce the number of poverty level and will ultimately improve the welfare of society. It has the meaning that the higher the investment that will lower the number of poor people. The state of foreign direct investment (FDI) and domestic investment (PMDN) in the Province of North Sumatra, according to data on the Central Statistics Agency (BPS) has experienced fluctuations on your new tablet. 
Marisa $\mathrm{Br}$ Sinuraya et.al. Analysis of effects of economic growth, human development index, population, unemployment and investment on poverty levels in the north sumatra province.

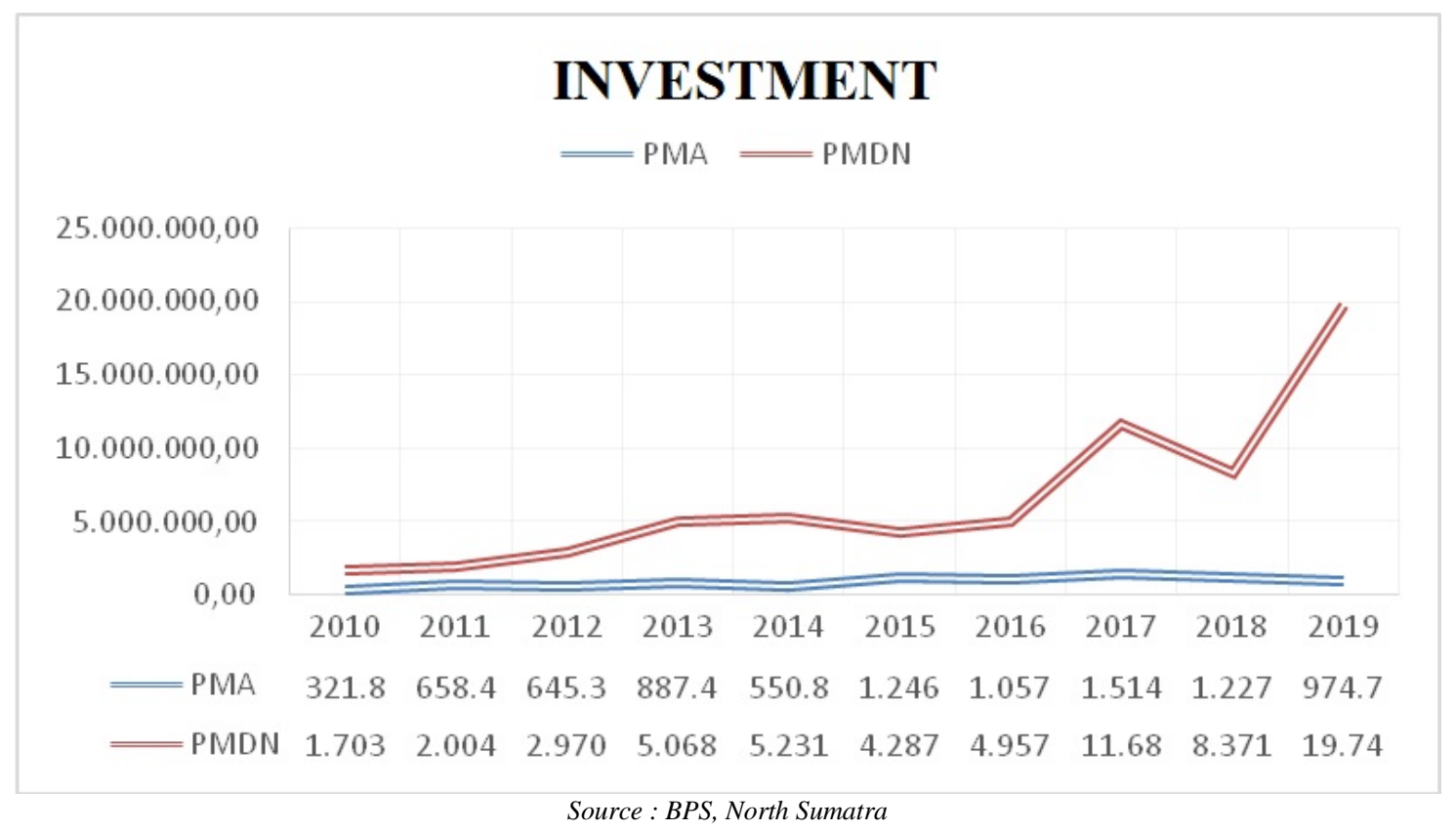

Figure 7 Development Of Investment In North Sumatra 2010-2019

Based on the figure 8 shows that the realization of the Investment Domestic investment (PMDN) in North Sumatra year 2010-2019 from year to year have fluctuated. In the year of 2019 is the highest number that is equal to $19.748 .995,10$ million, while the development of Foreign direct investment (PMA) showed a fluctuating movement. The highest numbers of foreign investment occur in the year 2017 amounted to 1.514.942,90 million. In 2015 the realization of the investment increased by 14.0 percent then in the next year decline in the level of poverty in the figure of a 10.53 percent. This figure shows that when both enhanced the effect to decrease the level of poverty, while the number of projects PMA and domestic investment over the last ten years is volatile.

In addition, some research related to poverty before the research is done Retnowati (2015), shows unemployment has a positive and significant influence on the number of poor. Then Budhijana (2019) states economic growth and no significant negative effect on the variable level of poverty, the HDI is a significant negative effect on the level of poverty and unemployment have a positive and significant impact on the variable level of poverty in Indonesia. The results of the research by Ritonga, Et al (2020) states GDP and a significant negative effect on the level of poverty and a variable number of the population has a positive influence on the level of poverty in the Coal District. Research Agustina, Et al (2018) said to the influence of the number of residents, the unemployment rate and the level of education on poverty shows that the level of unemployment and level of education have a positive and significant impact on poverty, while the number of the population does not have a significant effect on poverty. But according to Princess, Et al (2020) said variable economic growth has a positive effect on the level of poverty in Indonesia.

The differences in the previous studies above with this research is the independent variable used in the previous studies mentioned above only using at most three independent variables. While in this study, the researchers used four independent variables. Many years used in this study using ten years of research which is also divided into 4 quarter, so the period of observation research is also a lot more. Based on previous research that has been mentioned earlier, this study uses economic growth, HDI, population and unemployment as factors that can affect the level of poverty in the Province of North Sumatra. 
Marisa Br Sinuraya et.al. Analysis of effects of economic growth, human development index, population, unemployment and investment on poverty levels in the north sumatra province.

\section{LITERATURE REVIEW The Concept Of Poverty}

Poverty is a socio-economic condition of a person or group of people that are not fulfilled their basic rights to maintain and develop a better life (Act No.24, 2004).

\section{The Concept Of Economic Growth}

Economic growth is an important indicator used to describe the achievements and the development of something the economy. Todaro (2009:45) says that economic growth is defined as a process that causes a change in the life of the community, namely political change, social structure, social values, and the structure of the activities of the economy. Hashim (2016:232) economists agree that economic growth is defined as the increase in output of goods or materials and services within a certain period of time or in other words, is the process of increasing the production capacity of an economy which is manifested in the form of increase in national income.

\section{The Concept Of The Total Population}

According to BPS Indonesia, the population is all people who live in the region of the geographic of the Republic of Indonesia for 6 months or more and / or those who live less than 6 months but aims to settle. The population is an important element in economic activity and the effort to build the economy. In an effort to increase production and develop economic activity, population plays a very vital because it provides labor, corporate leaders, and entrepreneurs needed to create economic activity (Machmud, 2016: 238).

\section{The Concept Of Unemployment}

The World Bank said that the unemployment refers to for the labor force who are not working and are available to look for work. According to Hashim (2016:198) in general unemployment is a condition that indicates a resource that is not used. The resource in question is the labor. Labor is an indicator used to measure unemployment.

\section{The Concept Of Investment}

Investment is the expenditureexpenditure for the purchase of capital goods and equipment-production equipment with the aim to explore and especially add to the capital goods in the economy that will be used to produce goods and services in the future. Private investment is the expenditure or expenditure or capital investment company, to buy capital goods and completion-completion of production to increase the ability to produce the goods and services available in the economy (Sukirno, 2011:121).

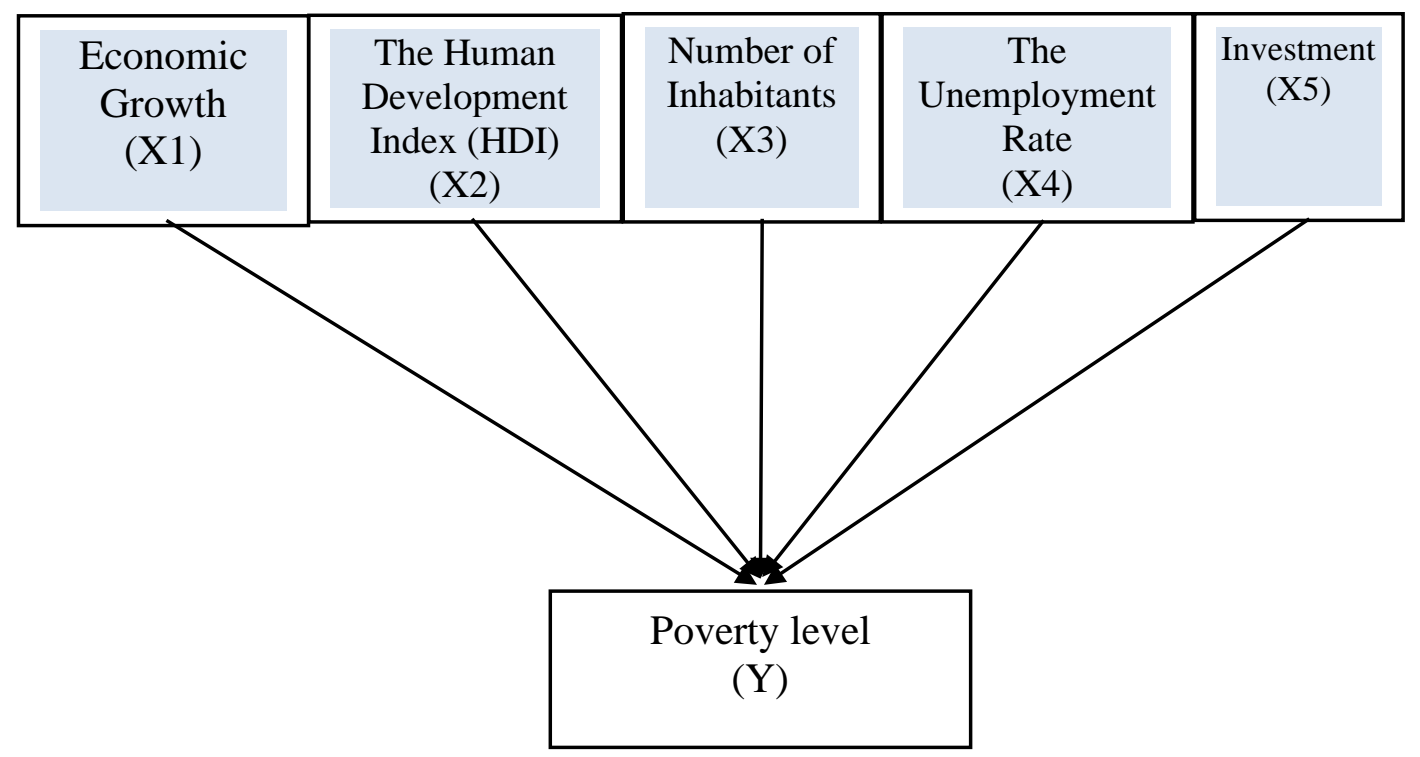

Figure 8 Conceptual Framework 
Marisa Br Sinuraya et.al. Analysis of effects of economic growth, human development index, population, unemployment and investment on poverty levels in the north sumatra province.

\section{Hypothesis}

Based on the background research and the relationship between variables, then the research hypothesis:

1. Economic growth negatively affects the level of poverty in the Province of North Sumatra.

2. The Human Development index negatively affect the level of poverty in the Province of North Sumatra.

3. The number of the population has a positive effect on the level of poverty in the Province of North Sumatra.

4. Unemployment has a positive effect on the level of poverty in the Province of North Sumatra.

5. Investment negatively affects the level of poverty in the Province of North Sumatra.

\section{MATERIAL AND METHODS}

The type of research used in this research is quantitative. According to Sugiyono (in Sinulingga, 2011:31) quantitative method is a research method which is based on the philosophy of positivism, is used to examine the population or a particular sample by using the instrument of data collection and analysis quantitative. Chosen quantitative methods in this research that discusses the influence of economic Growth, Human Development Index (HDI), population, Unemployment, and Investment, on the Level of Poverty in the Province of North Sumatra.
This study uses secondary data from official publications of the Central bureau of Statistics (BPS) of North Sumatra Province. Data analysis method used is the Autoregressive Distributed Lag (ARDL) and the observation period of this study, namely from the year 2010 until 2019 which will be conducted interpolation of the data, so a lot of the data period used in this study, 40 of the observation period.

The method of analysis is the approach used to analyze the influence of each independent variable on the dependent variable (the dependent variable). Refer to model cascading time (time series), in this research, there are some steps of the analysis, which includes the classical assumption test, test stationarity, the determination of the lag optimal, cointegration test, and the method ARDLECM (Autoregressive Distributed Lag-Error Correction Model).

\section{RESULT \\ Normality Test}

Normality test aims to test whether in the regression model confounding variables or residuals have a normal distribution. As it is known that the test and $F$ test assumes that the value of the residuals follow a normal distribution. If this assumption was violated then the test statistics to be invalid or number of samples is small. To test whether the distribution of data is normal or not, then do the test statistic Jarque-Bera Bera Test (J-B Test). Residual normal distribution if it has a significance value $>0,05$.

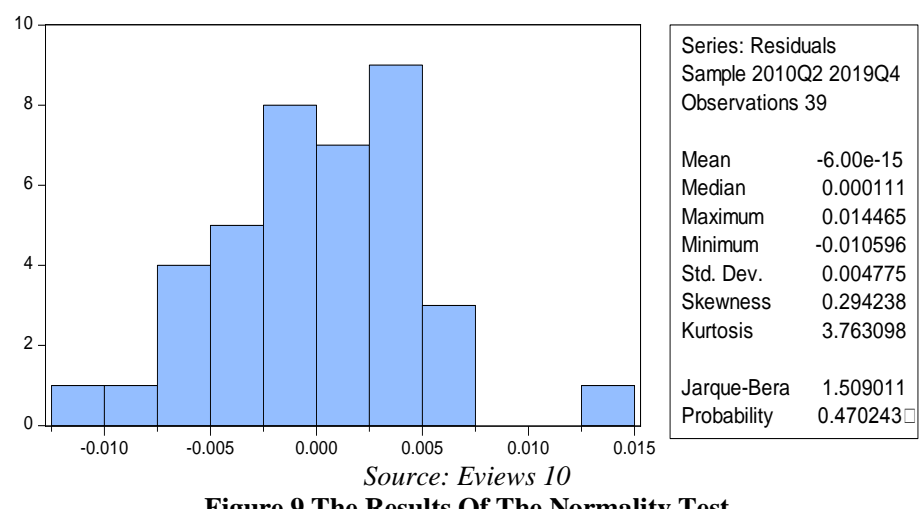

Figure 9 The Results Of The Normality Test 
Marisa Br Sinuraya et.al. Analysis of effects of economic growth, human development index, population, unemployment and investment on poverty levels in the north sumatra province.

Figure 9 shows the results of the normality test, dimanadapat concluded that all the variables used in this study, namely the level of poverty, economic growth, HDI, population, unemployment and investment have a significance level above 0.05 . Means the data used in this study has a distribution that is normal and shows the numbers probability 0,470 .

\section{B. Multicollinearity Test}

Multicollinearity test aims to test whether the regression model found a correlation between the independent variable (independent). The presence of multicollinearity resulting in difficulty in seeing the influence of the independent variable on the dependent variable. To detect the presence of multicollinearity can be used the value of the Variance Inflating Factor (VIF). If the value of VIF $<10$, then there is no multicollinearity. On the contrary, if the value of VIF $>10$, then there is multicollinearity.

Table 2 The Results Of The Multicollinearity Test

\begin{tabular}{|l|l|l|l|}
\hline & Coefficient & Uncentered & Centered \\
\hline Variable & Variance & VIF & VIF \\
\hline LOG(PE) & 0.003832 & 74.33390 & 6.626967 \\
\hline LOG(IPM) & 1.335522 & 60343.22 & 9.616215 \\
\hline LOG(JP) & 2.951239 & 888011.8 & 3.697232 \\
\hline LOG(TPT) & 0.003983 & 112.8065 & 4.518348 \\
\hline LOG(INV) & 0.022564 & 6212.296 & 7.349379 \\
\hline C & 5.446675 & 820572.9 & NA \\
\hline \multicolumn{4}{|r}{ Source: Eviews 10} \\
\end{tabular}

From Table 2 it can be seen that the value of the tolerance of all variables dependent (economic growth, HDI, population, unemployment and investment) is smaller than 10. It can be concluded that there was no multicollinearity in the model used.

\section{Heteroscedasticity Test}

It aims to test whether the regression model dissimilarity variance of the residuals one observation to the observation of others. Testing in this study using the BreuschPagan-Godfrey. Said to occur heteroscedasticity if the value of the probability of R-squared is smaller than 0.05 , and vice versa regression model that better not happen heteroskedasticities i.e. the value of R-squared greater of 0.05 .

Table 3 Results Of Heteroscedasticity Test

\begin{tabular}{|l|c|l|c|}
\hline \multicolumn{5}{|l|}{ Heteroskedasticity Test: Breusch-Pagan-Godfrey } \\
\hline F-statistic & 2.127284 & \multicolumn{1}{|c|}{ Prob. F(10,28) } & 0.0565 \\
\hline Obs*R-squared & 16.83769 & $\begin{array}{l}\text { Prob. Chi- } \\
\text { Square(10) }\end{array}$ & 0.0780 \\
\hline $\begin{array}{l}\text { Scaled explained } \\
\text { SS }\end{array}$ & 11.99045 & $\begin{array}{l}\text { Prob. } \\
\text { Square(10) }\end{array}$ & 0.2857 \\
\hline \multicolumn{4}{|c|}{ Source: Eviews 10 }
\end{tabular}

Based on Table 3 explains that the value of the probability of R-squared is greater than 0.05 , namely 0,07 so it can be concluded that this study did not experience heteroscedasticity.

\section{Autocorrelation Test}

Autocorrelation test aims to test whether in the model there is a correlation between the error clutter in the present period with the previous period. To see whether there is autocorrelation by using the test Durbin - Watson. As for the provisions in the testing of Durbin Watson is as follows:

a. Figure $\mathrm{D}-\mathrm{W}$ below the -2 means there autoorelasi positive.

b. Figure $\mathrm{D}-\mathrm{W}$ between -2 to +2 , it means there is no autocorrelation.

c. Figure $\mathrm{D}-\mathrm{W}$ above +2 means negative autocorrelation.

To know whether in the model there is a correlation between the errors of the bully in the period $t$ with an error of use in the period t-1 (formerly) the result can be seen in table 4 below:

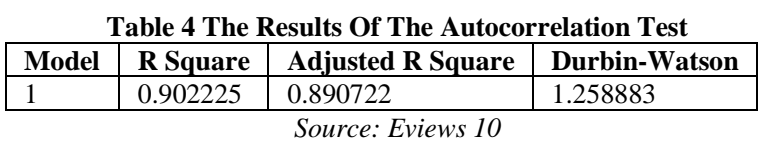

Based on the output table 4 the value of the Durbin-Watson resulting from the model is 1.25 in which the value is between -2 to 2 , so it can be concluded that in this test there is no autocorrelation.

\section{E. Test Of Stationarity: The Test Of The Root Unit Of The Dickey-Fuller}

Test stationary is done to see whether the data contains the root of the unit 
(unit root). Data is said to be stationary with the assumption that the mean and its variation constant. If the data has a root unit then it is said that data moves at random (random walk) and the data have the properties of random walk is said the data is not stationary. Conversely, if the data does not contain the root of the unit is the data that is stationary means that data has a range that is not too large or close to the average. In a test of the stationarity of the data can be done using the ADF at the same degree (level or different) to obtain the data stationary. Following the results of the stationarity of the data to the KINDERGARTEN, PE, IPM, JP, TPT, and INV method using the ADF.

Table 5 Test Results Of The Stationarity Of The Data Variables Of The Study

\begin{tabular}{|l|l|l|l|l|l|l|}
\hline Variable & Level & Description & First Difference & Description \\
\hline & t-stat & Prob & & t-stat & Prob & Significant \\
\hline TK & -0.155696 & 0.9351 & No Significant & -4.249537 & 0.0020 & Significant \\
\hline PE & -1.480316 & 0.5326 & No Significant & -3.089688 & 0.0358 & Significant \\
\hline IPM & 0.846412 & 0.9935 & No Significant & -3.004897 & 0.0442 & Significant \\
\hline JP & 0.082378 & 0.9599 & No Significant & -7.094858 & 0.0000 & Significant \\
\hline TPA & -1.335788 & 0.6019 & No Significant & -4.372934 & 0.0014 & Significant \\
\hline INV & 0.177494 & 0.9675 & No Significant & -3.150374 & 0.0312 & Significant \\
\hline \multicolumn{7}{|c|}{ Source: Secondary Data Processed (2021) } \\
\hline
\end{tabular}

Based on table 5 that the results of the test of the stationarity of the data TK, PE, IPM, JP, TPT, and INV, not stationary at level. This can be seen at the moment of order 0 (level), the p-value for each variable is greater than $\alpha=5$ persen, this means that the hypothesis $\mathrm{HO}$ is that there is a root unit on the data or the data is not stationary. As a result, all data need to be in differentiation in order to get stationary. After differentiation in the variable TK, PE, IPM, JP, TPT, and INV then stationary at order I (first difference). It can be seen that p-value for each variable is smaller than $\alpha=5$ percent that is to reject the hypothesis $\mathrm{HO}$ that there is no root units on the data or the data are stationary.

\section{F. Determination Of The Level Of Lag Optimal}

To determine the ARDL, should also determine how much lag that should be included in the model. There are several methods of model selection, namely the Akaike Information Criterion (AIC), Schwarz Bayesian Information Criterion (SBC) and Hannan-Quinn Criterion (HQ). Ekananda (2014:90) states that the magnitude of the lag that will be selected for each model is determined by the magnitude of the value of the Akaike Information Criterion (AIC). If the magnitude of a lag gives the smallest AIC value of the model, then the amount of lag that will be selected. While the pesaran et al (2001) stated that in determining the lag of the maximum, the approach is used Akaike Information Criterion (AIC) and Schwarz Bayesian Information Criterion (SBC). According to Foster and Sober (in Indiharwati, 2017) stated that the approach of the AIC provides an overview of the most close to reality, while the approach of the SBC is built to identify the model based on data that is owned and consistent statistically.

In this section, selection of the lag for the two parts of data that is the actual data and data transformation in the form of the natural logarithm. The selection of the lag was conducted to determine which model is the best among the two types of data. The selection of the lag is best done by looking at the value of the Akaike Information Criterion (AIC) of the model which produces the value of the smallest. In summary, the results of the selection of the lag from the actual data and the data transformation of the natural log is shown in the following image: 
Marisa $\mathrm{Br}$ Sinuraya et.al. Analysis of effects of economic growth, human development index, population, unemployment and investment on poverty levels in the north sumatra province.

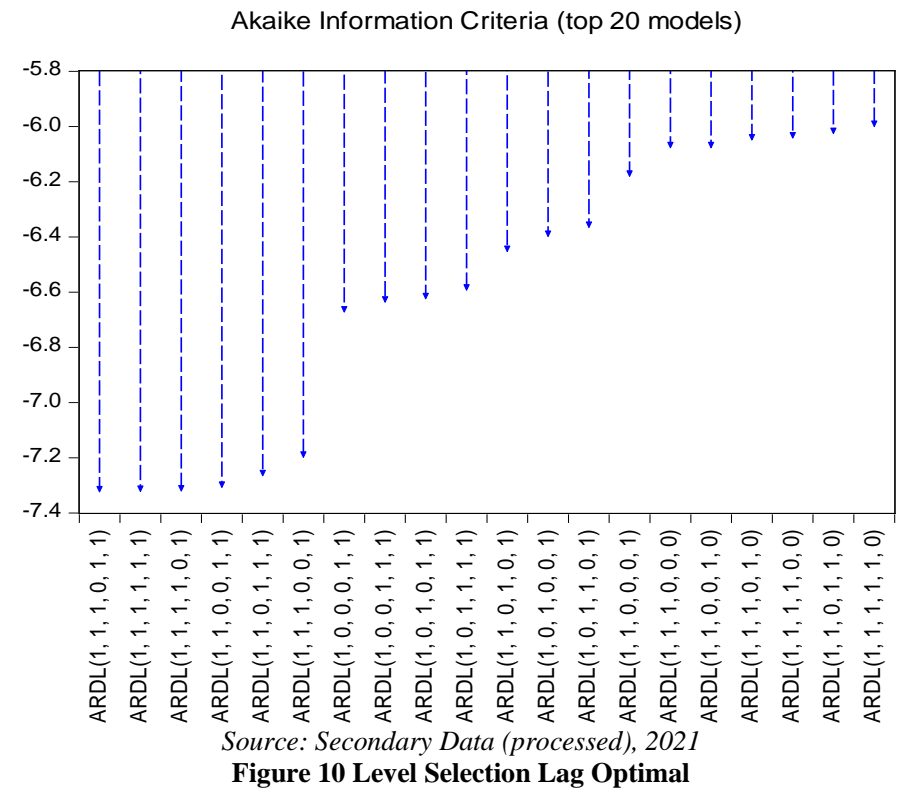

In figure 10 shows the results of the selection to the data transformation of the natural $\log$ of where all the AIC value negative value with the lowest value $-7,4$ who have by the model ARDL $(1,1,1,0,1,1)$. It is concluded that the best model for the data transformation logaritmaadalah model ARDL $(1,1,1,0,1,1)$.

\section{G. Cointegration Test}

The next step is to perform a cointegration test with the Bound Test. Test Bound (limit) is done to see whether there is a long-term relationship between the variables studied. In this approach, cointegration can be seen from the value of the $\mathrm{F}$ statistic with critical values that have been prepared by Pesaran (1997). Criteria decision-making is determined with nmelihat if the value of the $\mathrm{F}$ statistic is below the value of the lower bound, it can be concluded does not occur cointegration. Whereas if the value of the $F$ statistic is above the upper bound then dsimpulkan happened cointegration and if the value of the $\mathrm{F}$ statistic is between the upper bound and lower bound then the results can not be concluded. The results of the tests Bound on the model ARDL $(1,1,1,0,1,1)$ in a significance level of $1 \%, 2,5 \%, 5 \%$ and $10 \%$ is shown in the table below:
Table 6 Test Results Of The Bound Test Cointegration

\begin{tabular}{|l|l|l|}
\hline F-statisticValue4.536360 \\
\hline Significance & $\begin{array}{l}\text { I(0)Bound } \\
\text { (LowerBound) }\end{array}$ & $\begin{array}{l}\text { I(1)Bound } \\
\text { (UpperBound) }\end{array}$ \\
\hline $10 \%$ & 2.08 & 3 \\
\hline $5 \%$ & 2.39 & 3.38 \\
\hline $25 \%$ & 2.7 & 3.73 \\
\hline $1 \%$ & 3.06 & 4.15 \\
\hline \multicolumn{2}{|c|}{ Source: Secondary Data Processed (2021) }
\end{tabular}

From Table 6 explains that the results of the cointegration test using the approach of Bound Test shows the Fstatistic of 19,39923 and significant value within $5 \%$ with the value of I(0) Bound is equal to2,39 and the value of I(1) Bound of 3.38 Results of the cointegration test ARDL or Bounds testing cointegration show that the value of F-statistic is greater than the value of I(0) Bound and I(1) Bound 5\%. So it can be concluded that there is a cointegration between the variables of the study and can also be said that there is a long-term relationship between the variables of the study.

\section{H. Test The Stability Of The Model}

Stability test is used to determine the stability of the parameters in the short term and the Long term. The chart CUSUM and CUSUMQ significant at a confidence level of $5 \%$ indicates that the parameters of the stable. Here are presented the results of the test COSUM and CUSUMQ. 
Marisa Br Sinuraya et.al. Analysis of effects of economic growth, human development index, population, unemployment and investment on poverty levels in the north sumatra province.

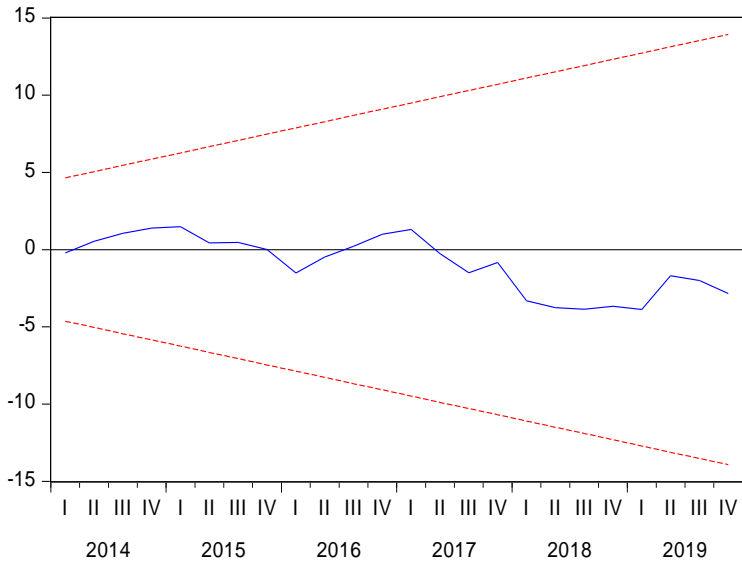

- CUSUM ---- 5 Persen Significance Source: Results Output Eviews 10

Figure 11 Chart of the Test CUSUM

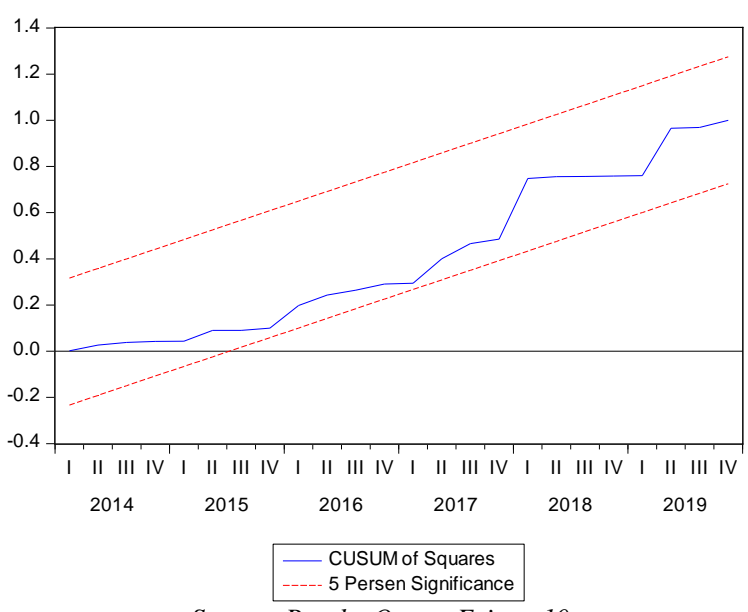

Source: Results Output Eviews 10

Figure 12 Chart Test CUSUMQ

Based on figure 11 and 12 can be seen test the stability of the model ARDL $(1,1,1,0,1,1)$ conducted to test the CUSUM and CUSUMQ with a significance level of 5 percent or confidence level of 95 percent. The image above shows the form of the diagram line of solid colored blue, which is between the two red dotted line which is the control of the stability of value-the value of the CUSUM and CUSUMQ at a confidence level of 95 percent. Can be seen from the image above that there is no da a solid line colored blue out of the line of control of the red dashed where it is shown that the model ARDL $(1,1,1,0,1,1)$ has been stable.

1. The Results Of The Estimation Of The Coefficient Of Long-Term And ShortTerm

2. Model ARDL (Autoregressive Distributed Lag) is a dynamic model that can see the influence of the variables $\mathrm{X}$ and $\mathrm{Y}$ from time to time, including the influence of $\mathrm{Y}$ from the past to the value of $Y$ the present, or in other words, can see the relationship long term and short term.

3. The last stage of the data analysis techniques using the method of ARDL is doing a test of the estimated coefficients of the long-term and short-term. Ekananda (2014:122) states that after the proven there is a relationship of cointegration between the variables, the next stage is to estimate the coefficients of the long-term.

Here are the results of the estimation of the coefficient of the Long-term in this study:

Table 7 Test Results Of The Estimation Of The Coefficient Of The Short-Term

\begin{tabular}{|l|l|l|l|l|}
\hline Variable & Coefficient & $\begin{array}{l}\text { Std. } \\
\text { Error }\end{array}$ & $\begin{array}{l}\text { t- } \\
\text { Statistic }\end{array}$ & Prob. \\
\hline C & 2.598967 & 1.217468 & 2.134732 & 0.0417 \\
\hline $\begin{array}{l}\text { LOG(TK(- } \\
1)^{*}\end{array}$ & -0.089224 & 0.032488 & $\begin{array}{l}- \\
2.746351\end{array}$ & 0.0104 \\
\hline LOG(PE(-1) & -0.168690 & 0.025691 & $\begin{array}{l}- \\
6.566120\end{array}$ & 0.0000 \\
\hline $\begin{array}{l}\text { LOG(IPM(- } \\
\text { 1) }\end{array}$ & -1.140342 & 0.297483 & - & 0.0007 \\
\hline LOG(JP)** & 0.517668 & 0.903795 & 0.572772 & 0.5714 \\
\hline $\begin{array}{l}\text { LOG(TPT(- } \\
\text { 1) }\end{array}$ & 0.052766 & 0.024296 & 2.171812 & 0.0385 \\
\hline $\begin{array}{l}\text { LOG(INV(- } \\
1)\end{array}$ & 0.014116 & 0.071516 & 0.197389 & 0.8449 \\
\hline CointEq(-1)* & -0.089224 & 0.006948 & - \\
\hline
\end{tabular}

Source: Secondary Data (processed), 2021

Based on the results of the estimation of the above by using the program E-Views 10 interpretation of the results of the estimation of the Short-term that is obtained is as follows

1. The value of the coefficient CointEq is a by- 0.089224 that shows the negative with a probability of 0.0000 which showed significant $(0.0000<0.05)$ then the ARDL can be accepted.

2. The coefficient of LOG(PE(-1) based on the estimation results obtained value of the coefficient of -0.168690 indicating negative with probability value of 0.0000 which means significant $\alpha=0.05$ percent $(0.0000<0.05)$, meaning that the economic growth of the previous quarter 
negatively affect the level of poverty in the short term, that is, when economic growth in the previous quarter rose 1 percent then it will lower the level of poverty quarter now of 0.089 percent assuming the other variables are considered constant. So, when economic growth is increased then it will lower the level of poverty in the short term.

3. The coefficient of LOG(HDI(-1) based on the estimation results obtained value of the coefficient of 1.140342 that shows the negative with a probability value 0.0007 , which means significant $\alpha$ $=0.05$ percent $(0.0007<0.05)$, meaning that the IPM the previous quarter negatively affect the level of poverty in the short term, that is, when the level of IPM the previous quarter rose 1 percent then it will lower the level of poverty quarter now amounted to 1.14 percent with the assumption that other variables are considered constant. So, when IPM is increased then it will lower the level of poverty in the short term.

4. The coefficient of LOG(JP) based on the estimation results obtained value of the coefficient of 0.517668 showing positive with a probability value 0.5714 which means not significant $\alpha=0.05$ percent $(0.5714<0,05)$. This means the amount of the population does not significantly affect the level of poverty in the short term.

5. Variable LOG(TPT(-1) based on the estimation results obtained value of the coefficient of 0.052766 that shows the positive with a probability value of 0.0385 which means significant $\alpha=0.05$ percent $(0.0385<0.05)$, meaning that unemployment the previous quarter positive effect on the level of poverty in the short term, that is, when unemployment the previous quarter rose 1 percent then it will be followed by an increase in the level of poverty quarter now amounted to 1.14 percent with the assumption that other variables are considered constant. So, when unemployment increases then it will be followed by an increase in the level of poverty in the short term.

6. Variable $\operatorname{LOG}(\operatorname{INV}(-1)$ based on the estimation results obtained value of the coefficient of 0.014116 that shows the positive value of the probability 0.8449 means not significant $\alpha=0.05$ percent $(0.8449<0.05)$ means that the investment in the previous quarter positive effect on the level of poverty in the short term, that is, when both the previous quarter rose 1 percent of the millions it will raise the level of poverty in the quarter now amounted to 0.014 percent assuming the other variables are considered constant. This means that when investment increases then it will be followed by an increase in the level of poverty in the short term.

Table 8 Test Results Of The Estimation Of The Coefficient Of Long-Term

\begin{tabular}{|l|l|l|l|l|}
\hline Variable & Coefficient & Std. Error & t-Statistic & Prob. \\
\hline LOG(PE) & -1.890647 & 0.661043 & -2.860099 & 0.0079 \\
\hline LOG(IPM) & -12.78074 & 4.101894 & -3.115813 & 0.0042 \\
\hline LOG(JP) & 5.801928 & 10.24375 & 0.566387 & 0.5756 \\
\hline LOG(TPT) & 0.591388 & 0.372609 & 1.587152 & 0.1237 \\
\hline LOG(INV) & 0.158215 & 0.800772 & 0.197577 & 0.8448 \\
\hline C & 29.12872 & 14.27905 & 2.039962 & 0.0509 \\
\hline
\end{tabular}

Source: Secondary Data (processed), 2021

The equation formed from the results of the estimation of the Long-term above is:

\section{$D=-1.890647 * P E-12.78074 * I P M+$ $5.801928 * \mathrm{JP}+$ 0.591388*TPT + $0.158215 * I N V+29.12872$}

Based on the results of the estimation of the above by using the program E-Views 10 interpretation of the estimation results of the long-term that is obtained is as follows :

1. Variable LOG(PE) and a significant negative effect on the level of poverty in the long term. It is seen based on the estimation results obtained value of the coefficient of -1.890647 with probability value of 0.0079 . Thus it can be concluded that the value of the probability variable $\mathrm{PE}$ is smaller than the significant level of $\alpha=0.05$ percent $(0.0079<0,05)$. This means increasing economic growth by 1 percent will lead 
Marisa Br Sinuraya et.al. Analysis of effects of economic growth, human development index, population, unemployment and investment on poverty levels in the north sumatra province.

to a decline of 1.89 percent on the the level of poverty in the long term.

2. Variable LOG(HDI) and a significant negative effect on the level of poverty in the long term. It is seen based on the estimation results obtained value of the coefficient of -12.78074 with probability value of 0.0042 . Thus it can be concluded that the value of the probability variable IPM smaller than the significant level of $\alpha=0.05$ percent $(0.0042<0,05)$. This means increasing the HDI of 1 percent will lead to a decrease of 12.7 percent in the level of poverty in the long term.

3. Variable LOG(JP) and no significant positive effect on the level of poverty. It is seen based on the estimation results obtained value of the coefficient of 5.801928 with a probability value 0.5756 . Thus it can be concluded that the value of the probability variables JP is greater than the significant level of $\alpha$ $=0.05$ percent $(0.5756<0,05)$. This means the amount of the population does not significantly affect the level of poverty in the long term.

4. Variable LOG(TPT) and no significant positive effect on the level of poverty. It is seen based on the estimation results obtained value of the coefficient of 0.591388 with a probability value of 0.1237 . Thus it can be concluded that the value of the probability variable TPT greater than the significant level $\alpha=$ 0.05 percent $(0.1237<0,05)$. This means unemployment does not significantly affect the level of poverty in the long term.

5. The coefficient of LOG(INV) and no significant positive effect on the level of poverty. It is seen based on the estimation results obtained value of the coefficient of -0.158215 with a value of probability 0.8448 . Thus it can be concluded that the value of the probability variable INV greater than the significant level $\alpha=0.05$ percent $(0.8448<0,05)$. This means that the investment does not significantly affect the level of poverty in the long term.

\section{DISCUSSION}

\section{The Influence Of Economic Growth On The Level Of Poverty}

Hypothesis 1 proposed in this study is thought to economic growth negatively affect the level of poverty. Results obtained from the calculation that the hypothesis 1 is proved. It shows the economic growth responded negatively and significantly in the short term and the long term. When economic growth increases, then the poverty will decrease. The results of this study are in line with Aderma (2019) says there is a negative relationship between economic growth and poverty level. This is in accordance with the opinion Siregar (2006) who said that economic growth is a requirement of necessity (necessary condition) to reduce poverty. As for terms adequate (sufficient condition) is that economic growth should spread evenly including among the poor population, so that the rate of poverty decline.

Economic growth has a positive impact on increasing the income of the public sector in the region. Economic growth indicates the increase in the production of goods and services, thus providing benefits in the form of added income for the people involved. According to Sukirno economic growth can be defined as the development of activities in the economy that cause the goods and services produced in the society increases. This means that with increase in economic indicating an increase in the demand will of goods and services. The results of this study in accordance with Dian Retnowati (2015) also conducted a study of regional economic growth has a negative influence on poverty. More Daftian (2017) argues that economic growth affect the level of poverty by looking at the level of significance of 0.004 . The relationship shown by the regression coefficient is negative, meaning that the higher the economic growth then the poverty rate will decrease. 


\section{The Influence Of The IPM On The Level Of Poverty}

Hypothesis 2 proposed in this study is allegedly IPM negative effect on the level of poverty. It shows that the IPM significant effect on the level of poverty in both the short and long term. Thus the hypothesis is accepted. It means that the relationship between the HDI and the level of poverty. This result is in line with research conducted Amirudin (2019) IPM and a significant negative effect on the level of poverty in Indonesia in the years 20142017. The results of the other supported also by the Budhijana (2019) analyze the economic Growth of a significant negative effect on the level of poverty, the HDI is a significant negative impact on the level of poverty, unemployment significant positive effect on the level of poverty in Indonesia suggested that the IPM negative effect and significant impact on the level of poverty. They say the source of human high will have an impact on the decline in the poverty rate. When the three components of the HDI, especially education increased then it can increase the knowledge, skills and absorb technology so as to create a skilled workforce, so it will be easy to meet the needs of life this will reduce the level of poverty. However, health is also an important factor in increasing productivity. Because with the existence of health, education will be able to be achieved. The dimensions of education and health is an important factor in lowering the poverty rate. According to Simmons (quoted from Todaro, 1994) that education in many countries is a way to save themselves from the poverty level, which is described by a poor man who expects employment as a high income then it should have a high level of education. Based on the level of education of the population of the poor of the year 2016 - 2019 increased to a higher level. 2016 education level high school to the top only amounted to 13.00 percent to 13.15 percent in 2019, an increase of 0.15 percent for the last 4 years. This suggests that the level of education of the population is poor is already better from year to year. Increasing the quality of education affects the decrease in the level of poverty in the Province of North Sumatra. The estimation results show that the level of education and the labor force participation rate has increased, but still a lot of unemployment in the Province of North Sumatra. This is caused by the education which does not lead to skills especially life skills, so despite the relatively high level of education but not necessarily be able to work because of the lack of skills and expertise so that it becomes unemployed, resulting in no income and being poor. Therefore, it is necessary efforts to improve the quality of human resources so that the productivity is increased. According to Fahmi (2015) that investment in education will be able to improve the knowledge and skilled. The higher the level of education a person if it is not followed by the expertise or skills will not be able to encourage and enhance work productivity.

\section{The Influence Of The Number Of Residents On The Level Of Poverty}

Hypothesis 3 proposed in this study is allegedly population has a positive effect on the level of poverty. Results obtained from the calculation that hypothesis 3 is proven and accepted. This shows in the short-term and long-term population responded positively but not significant in the Short term and the long term. The estimation results are in accordance with the research hypothesis that declares a variable of a Population has a positive effect on the variable Level of Poverty in the Province of North Sumatra where When the population increases it will be followed by the increasing level of poverty, as well as in accordance with the opinion by Todaro (2000) population growth raises the problem of underdevelopment and make the prospect of the establishment of the to further and further away. The growth of population coupled with the increase in jobs will only increase the number of unemployed. This 
will add to the burden hinders economic development. Unemployment can cause the level of poverty in a region to be increased. Results were not significant between the number of residents with the level of poverty in the Province of North Sumatra, and this shows that the population is not predominantly affects the level of poverty. This condition is caused due to the number of inhabitants in the Province of North Sumatra is dominated by the productive age so the chance of working to improve the lives of the still wide open. This is supported also by the BPS data when viewed by age group, the highest population in North Sumatra is a lot that is owned by the productive age of at the age of nonproductive. This also makes each year the population of labor force age 15 years and above (students) continues to increase, but they are still unable to meet basic needs because it is still in elderly dependents. In addition, the shift of labor from the primary sector to the secondary and tertiary sectors, this happens due to the shift of the growing season early, so that farm laborers switch to the industry and others, with so they can still meet the needs of his life. This research aligned to the research Wisnu Adi Syahputra (2011), which states that the number of the population has a positive effect on poverty, not in line with the research Elida Madonna Siburian (2018) suggested that the population negatively affect the level of poverty in the Province of North Sumatra 1999 - 2018.

The increasing number of population is the capital in economic growth, but with the proviso that a resident has the capacity of human resources are superior because all the inhabitants with the quality of human resources who will get a decent job. The increase in the population as boosters of the development that will empower a wide range of economic activities and will ultimately improve the welfare of society. On the other hand, population growth is also able to reduce the level of poverty. As one of the basic capital development, the number of large population. A large population also gives another advantage, which is the number of consumers of a variety of goods/products consumption. High demand for goods/ product consumption to be one of the factors supporting the growth of the economy. The growth of the economy in question is the quality economic growth. Then to get quality economic growth, it needs qualified Human resources as well.

\section{The Influence Of Unemployment On Poverty Level}

Hypothesis 4 proposed in this study is allegedly unemployment has a positive effect on the level of poverty. Results obtained from the calculation that hypothesis 4 is proven and accepted. This shows in the short-term unemployment in the response positive and significant but not significant in the long term. This is in line with the theory and some of the research which states that the unemployment significant positive effect on the level of poverty. According to Agenor (2004) relationship between unemployment and poverty is very strong so it will always be a trade-off between unemployment and poverty. Unemployment increases then the level of poverty will also increase. In line with the research Fitria Nurfauziah (2017) analyze the influence of GDP, the level of education and unemployment rates on the level of poverty in the Province of Jawa Tengah argued that unemployment has positive and significant effect on poverty. Unemployment is generally caused because of the amount of the labor force or job seekers are not comparable with the number of jobs that are able to absorb it. With rising unemployment, the value of the public revenue will go down, meaning that if income decreases the ability of society to meet the basic needs will also be decreased. According to Sukirno (2010:50) one of the important factors that determine the prosperity of a society is the level of income.

Factors that affect the expansion of employment opportunities, among others: 
the development of the population and the labor force, economic growth and wisdom of one factor of production is a very important addition to natural resources, capital and technology. Labor has a very important role in development, as development actors. The problem of employment is a problem that is so real and close to the environment. A high level of unemployment leads to low income further fueled the emergence of poverty (Yacoub, 2012). It is also in line with research Fitri Amalia (2012) states unemployment increases then the rate of poverty will also increase. However inversely proportional to the results of the study Ratih (2016) suggested unemployment has no significant effect on the level of poverty.

\section{The Influence Of Investment On Poverty Level}

The hypothesis proposed in this study is allegedly investment has a positive effect on the level of poverty. Results obtained from the calculation that hypothesis 5 is not accepted. This has the meaning that the increasing investment in the Province of North Sumatra then it will be followed by an increase in the number of poor people. In the short-term and long-term investment in response positive and not significant to the level of poverty. This research is in line with research Series Jefri Fair Waruwu with the title "Analysis of the Influence of Economic Growth, Unemployment, Government Spending and Investment On the Level of Poverty in Indonesia in the Years 1995-2015”. The results showed that both no significant positive effect on the level of poverty in Indonesia in the years 1995-2015.

Investment is the mobilization of resources to create or increase the capacity of production or revenue that will come. If all of the qualified labor actively involved in the economy, will increase the output of goods and services, which ultimately drive economic growth. Economic growth will create investment, create jobs to absorb the labor force that ultimately reduce poverty
(Seran, 2017). The results of this study also does not fit with the theory. According to Sukirno (2000) activities of the investment made by the community continuously will increase economic activity and employment opportunities, increase the national income and improve the standard of prosperity of society. This role is sourced from three important functions of investment activities, namely; (1) the Investment is one component of aggregate expenditure, so that the increase in investment will increase aggregate demand, national income and employment opportunities; (2) Accretion of capital goods as a result of the investment will increase production capacity; (3) Investment is always followed by the development of technology. In this study, it was found that the investment has a positive relationship and significant effect on poverty in the Province of North Sumatra. It is proved that the increase in investment might just be able to raise the national income, create jobs but not directly reduce poverty due to the gap relatively large investments in North Sumatra, so that the absorption of labor does not occur evenly in each area and causes the problem of unemployment. Increased investment in North Sumatra, but can not absorb labor to the maximum due to the investment used by the company to improve the technology or machinery in increasing the production capacity so that labor is not much absorbed. Research supported by Nengah Rai (2019), which states that the investment has a positive and not significant to the level of poverty in the Province of Bali. The presence of differences in the results of research with the existing theory can be caused due to investment in the form of portfolio investment or indirect investment where the investment inisifatnya investment are not involved directly so it is not able to absorb labor and can not reduce the level of poverty that exists. Investment in North Sumatra is a lot of domestic investment by 18.189.528,40 million dollars. Some investment sectors that contribute in North Sumatra, such as the construction of 
2.379.064,70 million dollars, housing for 2.088.557,10 million dollars, the industrial metal of $387.471,80$ million dollars, the estate of $301.823,10$ million dollars, the mining of 301.599,50 million rupiah (Source, BPS Sumatera Utara).

Investment activity should be done not only physical but non-physical such as investment in human resources in the field of education. Investment in education will be able to improve the quality of life ssumber human resources, which will push your skills. Increased knowledge and expertise will drive the productivity of a person, so the company will give you a higher salary for a workforce that is productive. This will improve the welfare of society and help them get out of the cycle of poverty. This study is not in line with the Research conducted by Yolanda Pateda. Vecky and Tri Oldy Rotinsulu in the Province of Gorontalo (2015) stated that the investment has a negative influence and significant impact on poverty levels. The investment made by the government of Gorontalo Province from year to year, have a positive impact on poverty reduction.

\section{CONCLUSIONS AND \\ RECOMMENDATIONS CONCLUSIONS}

Based on the results of the research can be summed up as follows:

1. Economic growth affects the level of poverty in both the short and Long term.

2. IPM affect the level of poverty in both the short and Long term.

3. The number of the population does not affect the level of poverty in the short term and the Long term.

4. Unemployment affect the level of poverty in the short term but not in the long term.

5. The investment does not affect the level of poverty in both the short and Long term.

\section{RECOMMENDATIONS}

Suggestions researchers from the research that has been done is as follows:
1. The government of North Sumatera Province remains accelerated its pace of growth, should seek quality economic growth and equitable to reduce the level of poverty as well as effective in distributing the benefits of economic growth because economic growth has a significant effect lowers the level of poverty. Development undertaken by the government should be more emphasis on sectors that can support economic growth and reduce poverty such as education, health, and other facilities. The government needs to add new programs and think long-term plan to reduce the level of poverty in North Sumatra, to the number of the poor will decrease.

2. Judging from the results of the study showed that the IPM significant negative effect on the level of poverty, so the need for the improvement of IPM because if HDI increases the number of poor people can be also reduced. In order to improve IPM then the government of North Sumatera Province need to improve infrastructure, particularly in the field of education and health. Provinsi Sumatera North is still not adequate in the field of education and health, so by increasing the means that can improve the quality of human resources in the Province of North Sumatra one of them to continue the program the Smart Indonesia Card (KIP), Healthy Indonesia Card (KIS) because of the impact on quality of life of the poor in the Province of north Sumatra.

3. The results showed that the number of the population and no significant positive effect on the level of poverty, so it is expected the North Sumatra Provincial Government must keep pace with the growth of the population with high economic growth.

4. The results showed that the unemployment rate has positive significant impact on poverty. In an effort to reduce the unemployment rate, 
Marisa Br Sinuraya et.al. Analysis of effects of economic growth, human development index, population, unemployment and investment on poverty levels in the north sumatra province.

the government should encourage job training programs to the labor force young age and entrepreneurship training to the general public.

5. The North Sumatra Provincial government should increase investment in every year, for a good investment is expected to provide increased revenue for the region of North Sumatra Province so also increases the productivity of labor in various sectors through the provision of skills training to the workforce in the Province of North Sumatra, the focus repair of existing infrastructure in the Province of North Sumatra as well as in an increase in human resources, which then is expected to be able to cope with the problem of poverty.

6. For the next researcher to consider and add to the other variables, which is associated with the level of poverty and increase the period of data research, so that research results become more relevant as a reference for poverty reduction in the Province of North Sumatra.

\section{Acknowledgement: None}

\section{Conflict of Interest: None}

\section{Source of Funding: None}

\section{REFERENCES}

1. Aderma, Emarisa, Dkk. 2019. Pengaruh Pertumbuhan Ekonomi dan Pengangguran Terhadap Kemiskinan di Sumatera Utara. Jurnal Ekonomi Pendidikan. Vol. 7, No. 3. Medan.

2. Adisasmita. R. 2013. Teori-Teori Pembangunan Ekonomi. Yogyakarta: GrahaI lmu.

3. Agustina, E., Syechalad, M. N., \& Hamzah, A. 2018. Pengaruh Jumlah Penduduk, Tingkat Pengangguran dan Tingkat Pendidikan Terhadap Kemiskinan di Provinsi Aceh. Jurnal Perspektif Ekonomi Darussalam. Vol. 4, No. 2, 265283.
4. Ajija, Shochrul. 2011. Cara Cerdas Menguasai Eviews. Jakarta: Salemba Empat.

5. Amalia, Nurisqi. 2018. Human Development Index, Unemployment And Poverty In Papua Province. Jurnal Ekonomi Pembangunan. Vol. 16, No. 01. Yogyakarta.

6. Amirudin. 2019. Pengaruh IPM dan Tingkat Pengangguran Terhadap Kemiskinan di Indonesia Tahun 20142017. Universitas Negeri Syarif Hidayatullah

7. Ariefianto, Doddy.2012. Ekonometrika: Esensidan Aplikasi Menggunakan Eviews. Jakarta: Erlangga.

8. Arsyad, Lincolin. 2010. Ekonomi Pembangunan. Yogyakarta: UPP STIM YKPN.

9. Astiyanti, Yeni. 2017. Perkembangan Pariwisata Terhadap Pengentasan Kemiskinan. Jurnal Fakultas Ekonomi dan Bisnis Universitas Brawijaya. Malang.

10. Badan Pusat Statistik. 2014. Sumatera Utara Dalam Angka.Provinsi Sumut.

11. Badan Pusat Statistik. 2015. Sumatera Utara Dalam Angka.Provinsi Sumut.

12. Badan Pusat Statistik. 2016. Sumatera Utara Dalam Angka.Provinsi Sumut.

13. Badan Pusat Statistik. 2017. Sumatera Utara Dalam Angka.Provinsi Sumut.

14. Badan Pusat Statistik. 2018. Sumatera Utara Dalam Angka.Provinsi Sumut.

15. Badan Pusat Statistik. 2019. Sumatera Utara Dalam Angka.Provinsi Sumut.

16. Bank Dunia. 2006. Era Baru Dalam Pengentasan Kemiskinan Di Indonesia : Bank Dunia.

17. Bappeda.2014. Rancangan Akhir Rencana Pembangunan Jangka Menengah Nasional (RPJMN) Provinsi Sumatera Utara Tahun 2015-2019. Bappeda Provinsi Sumatera Utara.

18. Bappeda. 2019. Rancangan Akhir Rencana Pembangunan Jangka Menengah Daerah (RPJMD) Provinsi Sumatera Utara Tahun 2018-2022. Bappeda Provinsi Sumatera Utara.

19. Bappenas. 2005. Rencana Strategis Penanggulangan Kemiskinan di Indonesia. 
Marisa Br Sinuraya et.al. Analysis of effects of economic growth, human development index, population, unemployment and investment on poverty levels in the north sumatra province.

20. Bappenas. 2018. Analisis Wilayah Dengan Kemiskinan Tinggi. Jakarta: Kedeputian Bidang Kependudukan dan Ketenagakerjaan.

21. Basuki, Agus Tri. 2017. Ekonometrika dan Aplikasi Dalam Ekonomi (Dilengkapi Dengan Aplikasi Eviews 11). Danisa Media. Yogyakarta.

22. Budhijana, Bambang. 2019. Analisis Pengaruh Pertumbuhan Ekonomi, Indeks Pembangunan Manusia (IPM) Dan Pengangguran Terhadap Tingkat Kemiskinan di Indonesia Tahun 20002017. Jurnal Ekonomi, Manajemen Dan Perbankan. Vol. 5, No. 1, 36-44.

23. Cox, David. 2014. Outline of Presentasion on Poverty Allevation Programs in the Asia-Pacific Regio. International Seminar on Curriculum Development of Social Work Education in Indonesia: Sekolah Kesejahteraan Sosial Bandung.

24. Eka Agustina. 2018. Pengaruh Jumlah Penduduk, Tingkat Pengangguran dan Tingkat Pendidikan Terhadap Kemiskinan di Provinsi Aceh. Jurnal Perspektif Ekonomi Darussalem. Vol. 4, No.2.

25. Fadila, Radiatul. 2020. Pengaruh Indeks Pembangunan Manusia (IPM) dan Pertumbuhan Ekonomi Terhadap Tingkat Kemiskinan di Provinsi Sumatera Barat Periode Tahun 2013-2018. Vol. 3, No. 1. Padang.

26. Fatmasari, Y. 2018. Pengaruh PDRB, Pendidikan Dan Pengangguran Terhadap Kemiskinan Di Jawa Timur 2006-2015. Universitas Brawijaya.

27. Fitria Nurfauziah. 2017. Pengaruh PDRB, Tingkat Pendidikan dan Jumlah Pengangguran Terhad ap Tingkat Kemiskinan di Provinsi Jawa Tengah 2009-2015. Universitas SunanKalijaga. Yogyakarta

28. Ghozali, Imam. 2011. Aplikasi Analisis Multivariate Dengan Program SPSS. Semarang: Badan Penerbit Universitas Diponegoro.

29. Gujarati, Damodar. 2007. Dasar- Dasar Ekonometrika. Jakarta: Salemba Empat.

30. Hasyim, Ali Ibrahim. 2016. Ekonomi Makro. Depok: Kencana.

31. Hereirah, A. $2005 . \quad$ Strategi Penanggulangan Kemiskinan. Jurnal Ilmu
Kesejahteraan Sosial Fakultas Ilmu Social Dan IlmuPolitik UNPAS-LSM Mata Air (Masyarakat Cinta Tanah Air). Bandung.

32. Jhingan, M. L. 2018. Ekonomi Pembangunan dan Perencanaan. Depok: PT. Raja Grafindo Persada.

33. Jhingan. M. L. 2010. Ekonomi Pembangunan dan Perencanaan. Jakarta: PT. Raja Grafindo Persada.

34. Jonaidi, A. (2012). Analisis Pertumbuhan Ekonomi dan Kemiskinan di Indonesia. Jurnal Kajian Ekonomi, Vol 1, No 1, 140164.

35. Kuncoro,Mudrajad. 2003. Ekonomi Pembangunan: Teori, Masalah danKebijakan. UPP AMP YKPN. Yogyakarta.

36. Kurniawan. 2011. Analisis Faktor-Faktor Penyebab Kemiskinan di Kabupaten Musi Banyuasin. Jurnal Ilmiah Ekonomi Global. Vol. 8, No.01. Palembang.

37. Leonita, Lily. 2019. Pengaruh PDRB, Pengangguran Dan Pembangunan Manusia Terhadap Kemiskinan Di Indonesia Tahun 2011-2017. Jurnal Ekonomi, Manajemen Dan Akuntansi. Vol. 2, No. 2, 1-8.

38. Machmud, Amir. 2016. Perekonomian Indonesia Pasca Reformasi. Jakarta:Erlangga.

39. Maipita, Indra. 2013. Memahami Mengukur Kemiskinan. Absolut Media :Yogyakarta.

40. Mankiw, N Gregory. 2018. Pengantar Makro Ekonomi. Jakarta: Salemba Empat.

41. Muthalib, Abd Aziz. 2015. Kewirausahawan (Studi Alternatif Pengentasan Kemiskinan Melalui UMKM).Kurnia Global Diagnostika: Yogyakarta.

42. Nadya, Zul. 2109. Analisis Kausalitas Kriminalitas, Pendidikan Dan Kemiskinan di Indonesia. Jurnal Ekonomi Dan Pembangunan. Vol. 1,No.2. Padang.

43. Nengah, Rai. 2019. Pengaruh Pengeluaran Pemerintah dan Investasi Terhadap Pertumbuhan Ekonomi dan Tingkat Kemiskinan di Provinsi Bali. Vol. 8, No.7, 651-680

44. Paramita Diah, dan Purbadharmaja. (2015). Pengaruh Investasi dan Pengangguran Terhadap Pertumbuhan 
Marisa Br Sinuraya et.al. Analysis of effects of economic growth, human development index, population, unemployment and investment on poverty levels in the north sumatra province.

Ekonomi Serta Kemiskinan Di Provinsi Bali. Jurnal Ekonomi Pembangunan Universitas Udayana.Vol. 4, No.10, 1194-1218.

45. Pateda Yolanda Dan Vecky. 2017. Pengaruh Investasi, Pertumbuhan Ekonomi Dan Pengeluaran Pemerintah Terhadap Tingkat Kemiskinan Di Gorontalo. Jurnal Pembangunan Ekonomi Dan Keuangan Daerah. Vol. 18, No. 6.

46. Primandari, Ratih. 2018. Pengaruh Pertumbuhan Ekonomi, Inflasi dan Pengangguran Terhadap Tingkat Kemiskinan di Sumatera Selatan. Jurnal Ekonomi Pembangunan. Vol. 16, No. 1, 1-10.

47. Putri, Megawati Dan Azhar. 2020. Pengaruh Pertumbuhan Ekonomi Terhadap Kemiskinan Tingkat Provinsi Di Indonesia. Vol. 4, No. 2, 144-149.

48. Ritonga, Marito. 2020. Pengaruh PDBR Dan Jumlah Penduduk Terhadap Tingkat Kemiskinan di Kabupaten Batu Bara Sumatera Utara Tahun 2010-2018. Jurnal Diversita. Vol.6, No. 1. Medan.

49. Segoro, Waseso. 2016. Analisis Pengaruh PDRB, Inflasi, Indeks Pembangunan Manusia (IPM) Dan Pengangguran Terhadap Kemiskinan di Indonesia Tahun 2009-2012. Jurnal Sosial, Ekonomi, dan Humaniora. Vol 6, No.1.Depok.

50. Seran, Sirilius. 2017. Hubungan Pendidikan, Pengangguran dan Pertumbuhan Ekonomi Dengan Kemiskinan. Jurnal Ekonomi Kuantitatif Terapan. Vol 10, No. 2, 59-71.

51. Seruni, SutrisnaKetut. 2014. Pengaruh PDRB Per Kapita, Pendidikan, Dan Produktivitas Tenaga Kerja Terhadap
Kemiskinan di Provinsi Bali. Jurnal Ekonomi Pembangunan. Vol. 3, No. 10. Bali.

52. Subri, Mulyadi. 2003. Ekonomi Sumber Daya Manusia Dalam Perspektif Pembangunan. Jakarta: PT Raja Grafindo Persada.

53. Sukirno, S.2004. Makro Ekonomi Teori Pengantar. Jakarta: Raja Grafindo Persada.

54. Sukirno, S. 2010. Makro Ekonomi Teori Pengantar. Jakarta: Raja Grafindo Persada.

55. Sukirno, S. 2011. Makro Ekonomi Teori Pengantar. Edisi Ketiga. Jakarta: Rajawali Pers.

56. Todaro, Michael P. 2006. Pembangunan Ekonomidi Dunia Ketiga. Jakarta: Erlangga.

57. Todaro, Michael P. dan Stephen C. Smith. 2011. Pembangunan Ekonomi (Edisi Kesebelas), Jilid 1). Jakarta: Erlangga.

58. Undang-Undang Pasal 31 Tahun 1945 Tentang Hak dan Kewajiban Dalam Pendidikan dan Kebudayaan.

59. UNDP (United Nation Development Programme Human Development Report. The Real Wealth Of Nations: Pathways To Human Development. New York.

How to cite this article: Marisa Br Sinuraya, Raina Linda Sari, Irsad Lubis. Analysis of effects of economic growth, human development index, population, unemployment and investment on poverty levels in the North Sumatra Province. International Journal of Research and Review. 2021; 8(12): 663-685. DOI: https:// doi.org/10.52403/ijrr.20211282 